\title{
Penyuluhan Manajemen Waktu Melatih Kedisiplinan Anak-Anak Didik Di Pondok Pesantren Asshiddiqiyah Tangerang Selatan
}

\author{
Jumino \\ Program Studi Pendidikan Ekonomi, Universitas Pamulang \\ dosen01803@unpam.ac.id
}

Naskah diterima: 28 Januari 2020; direvisi: 25 Februari 2020; disetujui: 20 Maret 2020

\begin{abstract}
Abstrak
Kedisiplinan merupakan sikap yang penting untuk dibiasakan sejak dini. Namun permasalahannya ketika anak-anak menginjak masa remaja kedisiplinan diri sudah mulai berkurang, padahal kediplinan bagian dari penanaman nilai-nilai karakter sehingga anak dapat mengatur dirinya sendiri. Oleh karena itu diperlukan perubahan paradigma anak-anak untuk mau bergerak dan mempunyai niat melakukan perubahan diri kearah yang lebih baik, maka dari itu diperlukan penyuluhan tentang manajemen waktu. Tujuan pengabdian ini diharapkan dapat memberikan pemahaman kepada siswa agar dapat menumbuhkan sikap disiplin yang dapat diterapkan dalam kehidupan sehari-hari. Metode pengabdian ini berupaya penyuluhan kepada anak-anak di Pondok Pesantren Asshiddiqiyah berjumlah 50 peserta. Hasil pengabdian kepada masyarakat ini adanya peningkatan pemahaman siswa terhadap kedisiplinan diri, hal itu dapat dibuktikan dengan adanya perubahan dalam keseharian siswa setelah adanya kegiatan ini. Siswa sangat antusias mengikuti kegiatan pengabdian masyarakat ini, hal ini dapat dilihat dari implementasi pengabdian masyarakat ini siswa dapat membuat jadwal untuk membiasakan disiplin, dan dengan kediplinan siswa termotivasi untuk dapat meraih kesuksesan dimasa depan.
\end{abstract}

Kata Kunci : Manajemen Waktu; Perubahan; Kedisiplinan

\begin{abstract}
Discipline is an important attitude to be used early. But the problem is when the children step in the youth of self-discipline has begun to diminish, when it is a part of planting character values so that the child can set himself up. It is therefore necessary to change the paradigm of children to want to move and have the intention of making self-change towards a better, then it is necessary counseling about time management. The purpose of this devotion is expected to provide understanding to students in order to foster a disciplined attitude that can be applied in daily life. This method of devotion seeks counseling to children in Pondok Pesantren Asshiddiqiyah amounted to 50 participants. The result of devotion to this society has increased students ' understanding of self-discipline, it can be proved by the change in daily students after this activity. Students are very enthusiastic to follow the activities of this Community devotion, this can be seen from the implementation of this community devotion students can make a schedule to familiarize the discipline, and with the student Kediplinan motivated to be able to achieve future success.
\end{abstract}

Keywords: Time Management; Change; Discipline 


\section{PENDAHULUAN}

Kediplinan merupakan kunci

kesuksesan seseorang, karena dengan adanya kediplinan seseorang dapat mengatur dirinya dengan baik. Pendidikan sebagai lembaga yang sangat penting untuk membiasakan siswa bersikap disipin. Kedisiplin bahkan harus dibiasakan sejak dini sebagai bukti bahwa siswa taat pada aturan yang berlaku baik dirumah maupun disekolah. Sebagaimana yang dijelaskan Abdurahman (2018) kedisiplinan merupakan proses latihan untuk memiliki ketaatan, ketertiban, kepatuhan, kesetiaan, dan dilakukan sebagai bentuk tanggung jawab diri. Berdasarkan pengertian tersebut, maka kediplinan sebagai bentuk perubahan perilaku untuk menjadi lebih taat aturan yang berlaku yang harus dijalani dengan baik. Oleh karena itu, kedisplinan harus dibiasakan sehingga dapat terinternalisasi dalam dirinya hingga anak beranjak dewasa.

Fenomena kediplinan dapat ditemukan diberbagai lembaga pendidikan. Salah satunya pada lembaga pendidikan di Pondok Pesantren. Berdasarkan hasil observasi yang kami lakukan sebelumnya di MTs Maba'ul Ulum Asshiddiqiyah, Pondok Pesantren Asshiddiqyah, Tangerang Selatan, ditemukan adanya beberapa fenomena dari para anak-anak didik dalam melakukan aktivitas sehari-hari kurang adanya kedisiplinan dalam menerapkan aturan yang ada di dalam Pondok Pesantren tersebut.

Salah satu permasalahan harus diperlukannya tingkat disiplin waktu kepada para santri khususnya anak-anak yang di usia SMP, dimana mereka akan menginjak masa remaja hal ini sangat membutuhkan perhatian terkait dengan penanaman nilainilai karakter, salah satunya adalah bagaimana mereka dapat mengatur diri sendiri yang berkaitan dengan kedisiplinan. Perubahan paradigma anak-anak didik tidak bisa didapatkan tanpa pembiasaan, anakanak harus diarahkan untuk mau bergerak dan mempunyai niat berubah kearah yang lebih baik, maka dari itu diperlukan penyuluhan dan pelatihan dan tips manajemen waktu.

Berdasarkan latar belakang tersebut, maka sangat penting dilakukan penyuluhan kepada pada siswa di Pondok Pesantren Asshiddiqiyah Tangerang Selatan tentang kedisplinan. Tujuan pengabdian ini diharapkan dapat memberikan pemahaman kepada siswa agar dapat menumbuhkan sikap disiplin yang dapat diterapkan dalam kehidupan sehari-hari. Sehingga manfaat perubahan sikap siswa menjadi lebih disiplin dapat memberikan dampak positif bagi diri 
siswa untuk mencapai kesuksesan dimasa depan.

Kedisiplinan yang dimiliki siswa diharapkan dapat diarahkan sehingga siswa memiliki rasa tanggung jawab terhadap diri sendiri dan kedisiplinan yang tumbuh berkembang di kalangan Para Santri dan tidak kalah pentingnya pembelajaran tersebut dapat diterapkan dalam kehidupan seharihari. Perubahan perlu proses peningkatan dari mengubah dari melihat ke mengubah untuk menjadi. Selama perubahan tersebut bergerak pada koridor peningkatan akan menghasilkan suatu tujuan yang ingin dicapai siswa.

\section{METODE}

Metode pengabdian masyarakat ini berupa kegiatan penyuluhan, kegiatan ini berguna untuk melatih dan meningkatkan kedisiplinan bagi anak-anak didik di MTs Manba'ul Ulum Asshiddiqiyah, Pondok Pesantren Asshiddiqiyah Tangerang Selatan. Jumlah siswa yang mengikuti kegiatan pengabdian masyarakat ini sebanyak 50 peserta.

Tempat pengabdian masyarakat dilakukan di MTs Manba'ul Ulum Asshiddiqiyah, Pondok Pesantren Asshiddiqiyah di Jalan Raya Puspitek, Gang Masjid, Kampung Setu RT.14 RW.4,
Kelurahan Setu, Kecamatan Setu, Tangerang Selatan. Kegiatan pengabdian berlangsung pada bulan November- Desember 2019.

Kegiatan pengabdian masyarakat ini dilakukan oleh dosen dan mahasiswa Program Studi Pendidikan Ekonomi, Fakultas Keguruan dan Ilmu Pendidikan Universitas Pamulang, sebagaimana yang ditunjukkan dalam gambar 1 sebagai berikut.

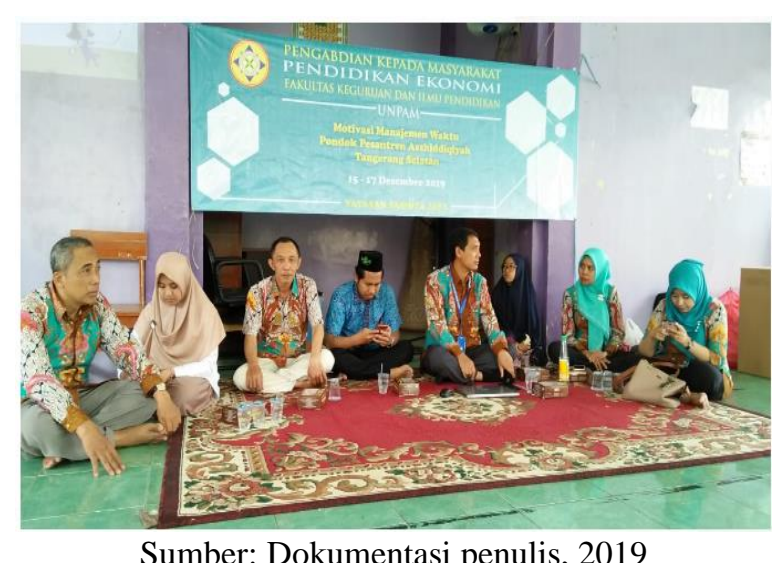

Gambar 1. Tim Dosen Pengabdian kepada Masyarakat

Kegiatan pengabdian kepada masyarakat ini disusun kedalam beberapa agenda yang telah dijadwalkan:

1. Persiapan, dimulai dengan kegiatan persiapan pengabdian kepada masyarakat dari mulai perencanaan sampai kepada pengurusan perizinan pengabdian.

2. Pembukaan, kegiatan ini berupa pengenalan dosen maupun mahasiswa dari tim pengabdi di tempat mitra pengabdian. 
3. Pemberian materi tentang :

a. Tips manajemen waktu

b. Memberikan motivasi manajemen waktu

4. Membuat pelatihan keterampilan dalam Menyusun jadwal secara mandiri

5. Kegiatan diskusi terkait dengan permasalahan yang dihadapi siswa terutama mengenai kediplinan.

6. Kegiatan evaluasi kegiatan pengabdian

7. Penutup.

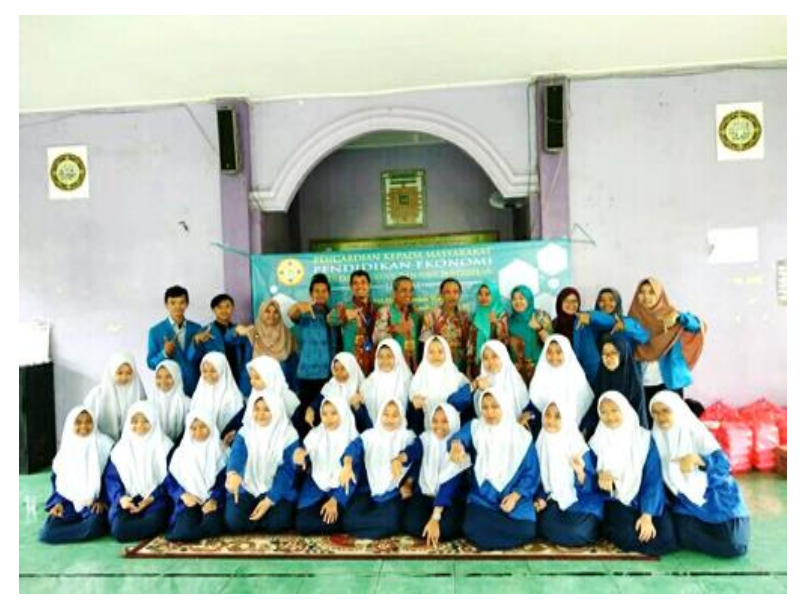

Sumber: Dokumentasi penulis, 2019

Gambar 2. Peserta Pengabdian kepada

Masyarakat: Perempuan

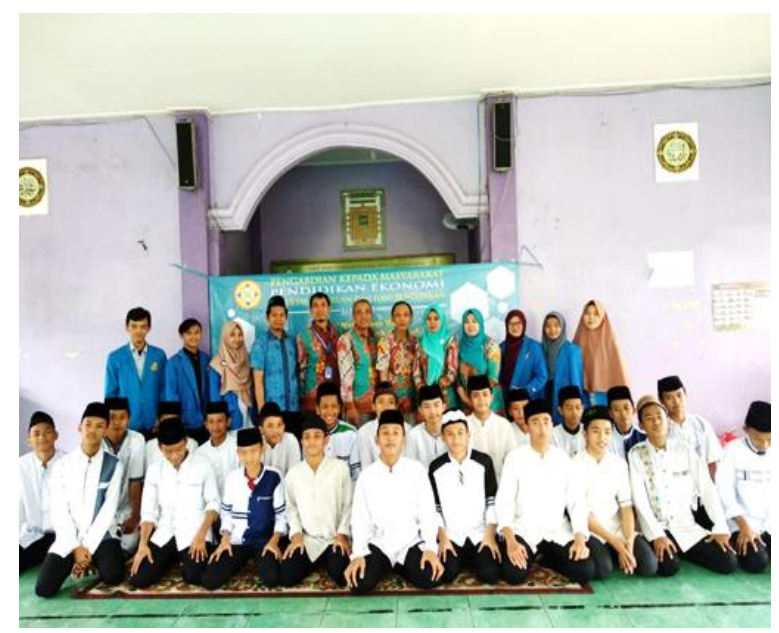

Sumber: Dokumentasi penulis, 2019

Gambar 3. Peserta Pengabdian kepada

Masyarakat: Laki-laki

Berdasarkan gambar 2 dan 3 menunjukkan bahwa siswa sangat antusias mengikuti kegiatan pengabdian kepada masyarakat yang telah dilakukan. Bahkan siswa sangat semangat untuk berdiskusi kepada tim dosen sehingga dapat menumbukan peningkatan motivasi diri siswa untuk menjadi yang lebih baik lagi 
kedepannya tentu dengan mengimplementasikan kediplinan diri diberbagai aspek kehidupan.

Dalam kegiatan pengabdian ini, tim dosen memberikan 10 Tips Manajemen waktu yang disampaikan yaitu:

1. Menghilangkan kebiasaan menunda Waktu, dimana hal tersebut tidak baik, jika pekerjaan sering ditunda, maka akan mengakibatkan banyak hal dampak perbuatan tersebut, dan itu semua cenderung akan negatif atau merugikan bagi diri sendiri.

2. Dahulukan Yang Wajib dan Prioritas, yaitu Dengan mendahulukan yang wajib dan prioritas inilah yang akan membuat ajang tonggak ritme hidup seseorang, sehingga akan menciptakan pola pemilihan waktu yang jelas dan tepat dalam kehidupan sehari-hari. Contoh: Ketika kita mempunyai janji dengan teman untuk bertemu, maka kita sering melibatkan waktu-waktu Shalat, nanti ketemuannya habis Shalat Zhuhur yaa.... !!!”, dengan demikian manajemen waktu kita dalam melakukan aktivitas dapat terprogram dengan baik.

3. Menyelesaikan Pekerjaan Tepat Waktu adalah, apabila diselesaikan secara cepat pada saat itu, maka alangkah lebih baik tidak mengundur waktu dalam pepatah mengatakan "lebih cepat adalah lebih baik".
4. Menentukan batasan waktu, yaitu untuk menghindari waktu yang hilang dengan sia-sia dan agar berjalan dengan efektif, maka diharuskan membuat batasan waktu dalam setiap kegiatan yang akan dilakukan. Contoh : waktu bermain, waktu Olahraga, waktu Tidur, waktu belajar dan sebagainya.

5. Meninggalkan Aktivitas Tidak Bermanfaat, adalah Kita dianjurkan meninggalkan kegiatan atau aktivitas yang tidak bermanfaat dan berlebihan, sebaiknya dikurangi atau sama sekali dihilangkan dari kehidupan kita, dalam hal ini masih terdapat banyak aktivitas bermanfaat lainnya yang dapat kita lakukan. Contoh : Tidur seharian, nonton TV yang berlebihan, bermain seharian, dan lain-lainnya.

6. Membuat jadwal kegiatan, adalah sangat penting, dari yang bersifat sederhana sampai dengan yang berbasis teknologi, agar waktu yang dimiliki berguna dan terisi untuk aktivitas yang bermanfaat sekaligus dengan ritme dan pola yang baik serta berjalan secara efektif.. Contoh: membuat daftar kegiatan / aktivitas kita yang dilakukan : harian, mingguan, bulanan dan bahkan tahunan jika diperlukan.

7. Kurangi Bersantai-santai, yaitu berusaha dengan giat dan keras tentu akan memetik hasilnya dengan setimpal apa 
yang mereka perbuat atau lakukan. Jika seseorang bersantai di dalam waktu yang dimilikinya, maka orang tersebut akan memperoleh hasil sesuai dengan usaha dan jerih payahnya.

8. Lupakan dan Jangan Terjebak Masa Lalu, agar waktu yang dimiliki tidak terbuang dengan sia-sia, maka kita harus optimis untuk terus menatap masa depan yang lebih cerah, hari esok harus lebih baik daripada saat ini dan seterusnya, sehingga tidak akan terjebak pada masa-masa lalu.

9. Belajar untuk lebih fokus pada sesuatu hal, yaitu jika kita memiliki banyak target yang ingin dicapai untuk mengejar mimpi dalam hidup, maka harus berusaha lebih fokus serta prioritas pada suatu hal, agar yang telah didapatkannya tidak terlepas, dan waktu yang dimiliki tidak hilang dengan sia-sia dan percuma.

10. Memiliki Niat untuk berubah Menjadi Lebih Baik, yaitu tidak ada seorangpun yang tidak menginginkan berubah menjadi yang lebih baik, namun niscaya hal tersebut tidak akan terlaksana atau tercapai manakala kita tidak memiliki niat yang kuat untuk berubah menjadi orang yang lebih baik, dimana waktu yang dimiliki harus dimanfaatkan secara maksimal mungkin agar bermanfaat untuk diri pribadi khususnya dan bagi orang lain pada umumnya, sehingga tidak akan menjadi golongan orang yang merugi.

Disamping memiliki rutinitas Jadwal di sekolah, mereka diarahkan berlatih membuat jadwal aktivitas-aktivitas yang akan dilakukan sepulang dari sekolah. Jadwal tersebut dalam bentuk tabel yang sifatnya sangat simpel, ataupun yang berbasis teknologi digital yang memuat jenis-jenis aktivitas waktu, serta memiliki cakupan dalam kegiatan belajar, kursuskursus, dan aktivitas lainnya. Dimana jadwal tersebut sangat efektif, guna melatih anak disiplin dalam beraktivitas, sehingga jadwal yang dibuatnya tidak akan terlewatkan. Jadwal pribadi ini, secara otomatis membuat anak akan mulai terpola, serta paham betul bahwa semua aktivitas bisa dituntaskan dengan baik sesuai jadwal mereka tetapkan, dan tentunya harus menggunakan perencanaan waktu dengan baik dan efektif.

Berlatih Mengukur Waktu, dengan tujuan melatih anak untuk dapat menentukan aktivitas atau kegiatannya dengan ukuran waktu yang tepat. Beberapa contoh dalam menentukan ukuran waktu, misalnya kegiatan sederhana seperti membereskan tempat tidur selama 5 -7 menit, kegiatan yang sifatnya menengah seperti mandi selama 10-15 menit dan kegiatan yang lebih besar lagi yang membutuhkan waktu dan 
konsentrasi lebih tinggi, belajar selama 3045 menit, dan beberapa aktivitas lainnya. Di Dalam memberikan motivasi atau stimulus , tidak ada salahnya jika memberikan hadiah kepada mereka Jam Tangan, dalam hal ini merupakan salah satu metode pembelajaran secara tidak langsung agar memanfaatkan Jam Tangan tersebut sebagai acuan memulai segala sesuatu dengan sesuai jadwal.

Membuat Jadwal Pribadi, Di Samping memiliki jadwal secara rutin yang ada di sekolah, mereka diarahkan berlatih pembuatan jadwal berisi aktivitas-aktivitas setelah dari Sekolah yang akan dilakukan. Adapun pembuatan jadwal tersebut bisa berupa tabel yang sifatnya sangat mudah dan sederhana untuk diimplementasikan, dan atau yang berbasis teknologi digital yang memuat jenis-jenis aktivitas yang mencakup hal-hal berkaitan belajar, kursuskursus, serta aktivitas lainnya. Jadi pembuatan jadwal pribadi tersebut sangatlah efektif untuk membuat anak berlatih dan salah satu pembelajaran memilah dan memilih aktivitas yang harusnya dapat dilakukan, dengan demikian aktivitas tersebut tidak ada yang terlupakan. Pembuatan jadwal pribadi tersebut, secara otomatis akan berdampak pada terpolanya anak untuk memahami, segala aktivitas bisa diselesaikan dengan sebaik mungkin, jika sesuai jadwal yang mereka telah tetapkan, dan tentunya harus menggunakan perencanaan waktu dengan baik dan efektif.

Melatih Anak Bertanggung Jawab dan Disiplin, dimana dengan pemberian pelatihan dan pembelajaran Manajemen Waktu ini, anak dapat menerapkan dalam menyelesaikan pekerjaan atau rutinitas sehari-hari, serta memberikan dorongan, motivasi pembuatan jadwal pribadi yang tentunya berkaitan dengan kegiatan-kegiatan , aktivitas - aktivitas dan tugas-tugas yang mereka miliki, dengan harapan hal ini secara otomatis akan berdampak pada pembelajaran kepada Anak untuk bertanggung jawab sesuai dengan jadwal yang telah dibuatnya. Berbicara Disiplin tentunya harus dimulai dari dini, tidaklah mudah seperti membalikan telapak tangan, namun Orang Tua harus bersabar dan perlu berperan aktif dalam mendampingi anak, dan tidak kalah penting Orang Tua atau orang terdekatnya harus sebagai panutan atau role model, karena secara tidak langsung akan berdampak padanya. Pembentukan kedisiplinan yang rendah akan terbentuknya anak terhadap kurangnya kemandirian, hal ini akan menjadikan hambatan internal mereka dalam menggapai cita-cita di kemudian hari, jika hal ini dibiarkan akan mengkristal karena Karakter yang sudah mendarah daging atau gabungan kebiasaankebiasaan dari setiap orang. 
Penelitian tentang kesiplinan siswa pernah dilakukan Tho'iin (2019) hasil penelitian menunjukkan bahwa upaya yang dapat dilakukan dalam memupuk kedisplinan siswa memberikan tata tertib, nasihat, memberikan hukuman. Selaras dengan hasil penelitian Silmi (2018) pembentukkan karakter mandiri dan disiplin lewat pembiasaan, nasihat, keteladanan, dan hukuman. Dengan kedisiplinan dapat membantu siswa merubah perilakunya kearah yang lebih baik sesuai dengan aturan yang berlaku di pesantren.

Kedisiplinan sangat berpengaruh pada kualitas pendidikan, bahkan berdasakan penelitian jika siswa disiplin maka sangat berpengaruh pada kualitas kehidupan pendidikan di sekolah tersebut. Hal ini selaras dengan hasil penelitian yang dilakukan Afiati (2018) terdapat hubungan yang positif dan signifikan antara kualitas kehidupan sekolah terhadap kedisiplinan santri asrama pondok pesantren.

Pengabdian masyarakat sangat bermanfaat bagi siswa, berdasarkan tips yang diberikan dapat meningkatkan pemahaman siswa agar lebih disiplin. Pengabdian masyarakat ini juga memberikan peningkatan keterampilan dalam membuat jadwal kegiatan sehari-hari. Dengan adanya kediplinan siswa akan lebih termotivasi untuk dapat meraih kesuksesan dimasa depan.

\section{KESIMPULAN}

Kegiatan pegabdian masyarakat dapat berjalan secara efektif sesuai dengan yang direncanakan dari awal sampai akhir kegiatan. Para peserta dapat memahami manajemen waktu untuk bertanggung jawab, mengatur diri sendiri dan melatih kedisiplinan.

Siswa sangat antusias mengikuti kegiatan pengabdian kepada masyarakat yang telah dilakukan. Bahkan siswa sangat semangat untuk berdiskusi kepada tim dosen sehingga dapat menumbukan peningkatan motivasi diri siswa untuk menjadi yang lebih baik lagi kedepannya dengan mengimplementasikan kedisiplinan diri diberbagai aspek kehidupan.

\section{REFERENSI}

Abdurahman, A. (2018). Budaya Disiplin dan Ta'zir Santri di Pondok Pesantren. Al-Riwayah: Jurnal Kependidikan, 10(1), 29-57.

Afiati, N. S. (2018). Kualitas Kehidupan Sekolah dan Disiplin pada Santri Pondok Pesantren. Insight: Jurnal Ilmiah Psikologi, 20(1), 15-28.

Silmi, I. (2018). Pembentukan Karakter Mandiri dan Disiplin pada Santri 
Asrama Peguruan Islam Pondok Tho'iin, R. (2019). Upaya penegakan

Pesantren Salaf Al-Anwar Bogangin

Kecamatan Sumpiuh Kabupaten

Banyumas. (Doctoral dissertation, IAIN Purwokerto). disiplin santri pondok pesantren Assalam Bangilan Tuban (perspektif bimbingan konseling islam) (Doctoral dissertation, UIN Walisongo). 
Biarkan halaman ini tetap ada

[ halaman ini sengaja dikosongkan ] 